\title{
Apresentação do volume 29
}

\author{
Introduction to no. 29
}

\author{
Lineide do Lago Salvador Mosca*
}

Tradução de

John Milton **

" Presidente da Comissão de Publicações do CITRAT e editora executiva da TradTerm. Docente da Universidade de São Paulo.

** Docente da Universidade de São Paulo. 
MosCA, L. do L. S. - Apresentação do volume 29

É com grande satisfação que apresentamos mais um número da TradTerm. As matérias enviadas têm sido numerosas e de qualidade, acompanhando os avanços dos estudos da tradução e terminológicos e propondo novas experiências nesses campos de atuação.

A estrutura do presente volume constitui-se de artigos voltados para a tradução literária, artigos com ênfase na teorização e artigos do campo da terminologia, sendo pois agrupados conforme esses domínios, contemplados pela Revista. Seguem-se duas matérias muito oportunas de tradução que enfocam assuntos polêmicos e que despertam grande interesse pela atualidade das questões neles debatidas. Por último, encerra o volume uma resenha de grande valor para os pesquisadores das teorias da tradução e aqueles que se dedicam a sua aplicação.

"O escritor-tradutor: diálogos poéticos no texto traduzido. 0 caso de Mário Quintana tradutor de Proust" - o artigo permite verificar em que medida o estilo do escritor interfere no estilo do tradutor, partindo-se da ideia de que o tradutor tem também seu estilo ao retextualizar, na condição de escritortradutor, caso de Mário Quintana.

"Lesbos: uma nova tradução do poema de Charles Baudelaire, seguida de comentários" - o artigo compõe-se de duas partes: a tradução de "Lesbos" e os comentários, introduzindo a noção de invariantes e variações na prática tradutológica, proposta por Meschonnic e a preocupação cultural na recepção do poema em questão.

"Uma análise descritivo-comparativa de duas traduções para o português brasileiro da obra Death of a Salesman" - Analisam-se excertos de duas traduções da obra que, sendo um texto dramatúrgico, inclui forçosamente a dimensão cênica, isto é, a sua enunciação em cena, não se tratando simplesmente do plano de tradução literária.

"Adaptação transcultural na tradução do questionário 'Quality of life in swallowing Disorders (SWAL-QOL)' para o português do Brasil" - o artigo apresenta um estudo de caso original sobre disfagia, dificuldade para engolir, 
MosCA, L. do L. S. - Apresentação do volume 29

com uma equipe multidisciplinar, envolvendo uma fonoaudióloga, apresentando problemas de tradução e sua possível adaptação à realidade brasileira.

"Interpretação automática ou tradução automática de fala: conceitos, definições e arquitetura de software" - o artigo traz uma visão geral de como se compõem algoritmos para intepretação automática, sobretudo os que remetem à fala acusticamente realizada.

"Units of Translation Adopted in Persian Term-formation - o artigo tem como objetivo examinar a tradução de prefixos do inglês para o persa pela APLL (Academy of Persian Language and Literature), utilizando como corpus os 11 volumes da Collection of Terms da referida Academia, publicados de 2004 a 2014.

"Extração de conhecimento: métodos de identificação de relações terminológicas aplicadas ao português do Brasil" - o artigo aponta as relações entre tradução e terminologia, utilizando a área da economia para exame, com possíveis aplicações a outros domínios.

“Glossário - Termos do Modelo de House de avaliação de traduções para tradutores e estudiosos da tradução". O trabalho propõe divulgar o glossário em português dos termos do Modelo de House para avaliação de traduções, no que se refere a termos dos conceitos mais importantes aos estudos tradutológicos.

Compõem o presente volume duas traduções de textos dos autores, Henri Meschonnic ("Traduzir não o que as palavras dizem, mas o que elas fazem") e Olga Castro Vásquez (“(Re)examinando horizontes nos estudos feministas de tradução: em direção a uma terceira onda?”) que discutem problemas bastante atuais no quadro dos estudos de tradução.

Encerrando, tem-se uma resenha, a que o autor denominou "O livro dos sonhos", acerca do livro de Johanna Klute e Klaus Küpper intitulado Kinder und Jugendbücher aus Lateinamerika. Kommentierte bibliographie der deutschen Ubersetzungen.Mit einem Vorwort von Thomas Sträter [Livros para crianças e 
MosCA, L. do L. S. - Apresentação do volume 29

jovens da América Latina. Bibliografia comentada das traduções alemãs. Com um prefácio de Thomas Sträter]. 0 estudo versa sobre a recepção dessas obras nos países de expressão alemã, tendo como base o Archiv für übersetzte Literatur aus Lateinamerika und der Karinik [Arquivo para literatura traduzida da América Latina e do Caribe. Bibliografias, Tomo 03]. 0 título da resenha é bastante sugestivo, por ser aberto a múltiplas interpretações, que vão do imaginário infanto-juvenil às grandes aspirações dos pesquisadores.

Os artigos que nos chegaram e que estão em fase de avaliação, quando fechamos este volume, se aprovados ficarão para o número seguinte.

Lembramo-nos da colaboração do Prof. Dr. John Schmitz, como autor e parecerista, falecido recentemente, e deixamos aqui registrada a nossa homenagem póstuma, com grande pesar pela perda que ele representa no âmbito das Ciências da Linguagem e entre os inúmeros amigos que deixou.

Agradecimentos muito especiais aos pareceristas que, com sua expertise, foram de grande valia na seleção das matérias enviadas e no aprimoramento de muitas delas, oferecendo-lhes oportunas sugestões. Expressamos também uma menção de apreço à colaboração do Prof. John Milton e ao trabalho da secretária do CITRAT, Sandra Albuquerque, e ao da atual monitora-revisora, Caroline Micaelia.

No aguardo de que continuemos a receber estudos de qualidade e pioneiros, que possam incentivar os cultivadores das áreas de conhecimento aqui expostas, desejamos a todos os leitores uma proveitosa fruição.

It is with great pleasure that we present another issue of TradTerm. The high-quality material we have received reflects the advances in translation and terminological studies and opens up new fields of action.

The structure of this volume consists of articles focused on literary translation, theory, and terminology, articles are grouped according to these domains, and are followed by two very timely studies that focus on 
MosCA, L. do L. S. - Apresentação do volume 29

controversial issues. Finally, the volume closes with a review of for researchers in translation theory and application.

"The writer-translator: poetic dialogues in the translated text. The case of Mario Quintana, translator of Proust" examines the extent to which the style of the writer interferes in the style of the translator, starting from the idea that the translator also has his own style in his recontextualization as a writertranslator, as in the case of Mário Quintana.

“'Lesbos': a new translation of the poem by Charles Baudelaire, followed by commentary" consists of two parts: the translation of "Lesbos" and the commentary, introducing the notion of invariants and variations in the translation practice proposed by Henri Meschonnic, and the cultural concerns when the poem in question reaches a new culture.

"A descriptive-comparative analysis of two translations into Brazilian Portuguese of Death of a Salesman" analyses excerpts of two translations of this important dramatical text, which necessarily includes the scenic dimension, and not simply the mere literary translation.

"Cross-cultural adaptation in the translation of the questionnaire 'Quality of life in swallowing disorders (SWAL-QOL)' into Brazilian Portuguese" presents an original case study on dysphagia, difficulty in swallowing, with a multidisciplinary team involving a speech therapist, presenting translation problems and their possible adaptation to Brazilian reality.

"Automatic interpretation or automatic translation of speech: concepts, definitions and software architecture" provides an overview of how to compose algorithms for automatic interpretation, especially those that refer to acoustic speech.

"Units of translation adopted in Persian term-formation" examines the translation of prefixes from English into Persian by the APLL (Academy of Persian Language and Literature), using as a corpus the eleven volumes of the Collection of Terms of the Academy published from 2004 to 2014. 
MosCA, L. do L. S. - Apresentação do volume 29

"Extraction of knowledge: methods of identification of terminological relations applied to Brazilian Portuguese" points out the relations between translation and terminology, examining Economics texts, with possible applications to other fields.

“Glossary - Terms of House's Model of Translation Evaluation for Translators and Scholars of Translation" proposes a publication of the glossary in Portuguese of the terms of Juliane House's Model for the evaluation of translations, in terms of the most important concepts for translation studies.

This volume also includes translations of the texts of Henri Meschonnic, "Translating not what words say, but what they do", and Olga Castro Vásquez "(Re)examining horizons in feminist translation studies: towards a third wave?", both of which discuss current problems in translation studies.

To conclude, there is a review, "The book of dreams", on the work of Johanna Klute and Klaus Küpper, Kinder und Jugendbücher aus Lateinamerika. Kommentierte bibliographie der deutschen Ubersetzungen. Mit einem Vorwort von Thomas Sträter [Books for children and young people from Latin America. Bibliography of the German translations. With a preface by Thomas Sträter]. The study deals with the reception of these works in German-speaking countries, based on the Archiv für übersetzte Literatur aus Lateinamerika und der Karinik [Archive for translated literature from Latin America and the Caribbean. Bibliographies, Volume 03]. The title of the review is very suggestive, because it is open to multiple interpretations, ranging from the imaginary to the aspirations of the writers.

We are now evaluating the articles we have received, which, if approved, will be published in the next issue.

We would like pay homage to Prof. Dr. John Schmitz, who collaborated with TradTerm as an author and reviewer, and who recently sadly passed away. His contributions to the Sciences of Language will be remembered by his many friends and colleagues. 
MosCA, L. do L. S. - Apresentação do volume 29

Special thanks are made to the referees who, with their expertise, have been of great help in the selection of the materials sent and the suggestions for the improvement of many of them. We would also like to thank the help of Prof. John Milton and the CITRAT secretary, Sandra Albuquerque, as well as the monitor-proofreader, Caroline Micaelia.

Hoping to receive more original and high-quality studies, which will help to develop research in the area, we hope readers enjoy this issue of TradTerm. 